\title{
THE ANALYTICAL SCORING ASSESSMENT USAGE TO EXAMINE SUNDANESE STUDENTS' PERFORMANCE IN WRITING DESCRIPTIVE TEXTS
}

\author{
Dedi Koswara *, Ruswan Dallyono, Agus Suherman, Pandu Hyangsewu \\ Universitas Pendidikan Indonesia, Bandung, Indonesia \\ *e-mail: dedi.koswara@upi.edu
}

\begin{abstract}
Many scholars view writing as a highly laborious task because many subcomponents are to be moulded into a single discourse. This issue is also faced by Indonesian higher education students, particularly sophomore students of the department of Sundanese language education. Therefore, this present study aims to uncover the factual evidence of whether the use of a rubric can enhance valid judgment. This process employed a validity and reliability scoring system. Subsequently, it is also significant to examine the functions of a rubric to promote sophomores' learning and develop instruction from lecturers in the department of Sundanese language education. This study objectively assesses students' descriptive writing in Sundanese language by considering the analytical scoring assessment functions. It turns out that the outcomes motivated the lecturers to constantly simplify the criteria in order to fit sophomores' descriptive texts, discover significant features, and incorporate the qualities into their own text insights. Furthermore, depending on the text complexity, such as intermediate, preadvanced, and advanced writing, as well as students' writing competence and maturation, lecturers may modify the analytical rubric that moderately recommends the necessary qualities of descriptive texts or encompasses a wider component of rubrics qualities. This finding implies that the analytical scoring rubric incorporates the influential scoring method into daily activities.
\end{abstract}

Keywords: Analytical scoring, descriptive text, validity and reliability, Sundanese education

\section{PENGGUNAAN PENSKORAN ANALITIK UNTUK MENILAI PENINGKATAN KEMAMPUAN SISWA MENULIS TEKS DESKRIPSI DALAM BAHASA SUNDA}

\begin{abstract}
Abstrak: Banyak orang mendefinisikan menulis sebagai tugas yang sangat melelahkan karena banyak subkomponen yang diperlukan untuk digabungkan sebagai satu wacana. Masalah ini juga dihadapi oleh mahasiswa pendidikan tinggi Indonesia, khususnya mahasiswa tingkat dua jurusan pendidikan bahasa Sunda. Oleh karena itu, penelitian ini dimaksudkan untuk mengungkap bukti faktual apakah penggunaan rubrik dapat meningkatkan penilaian yang valid. Proses ini menggunakan sistem penilaian validitas dan reliabilitas. Setelah itu, penting juga untuk mengkaji fungsi rubrik untuk mendorong pembelajaran mahasiswa tingkat dua dan mengembangkan pengajaran dari dosen di jurusan pendidikan bahasa Sunda. Penelitian ini secara objektif dimaksudkan untuk melakukan penulisan deskriptif mahasiswa dalam bahasa Sunda dengan mempertimbangkan fungsi penilaian skor analitik. Hasilnya memotivasi dosen untuk terus-menerus menyederhanakan kriteria agar sesuai dengan teks deskriptif mahasiswa tingkat dua dua, menemukan fitur yang signifikan, dan memasukkan kualitas ke dalam wawasan teks mereka sendiri. Selanjutnya, tergantung pada kompleksitas teks, seperti menulis menengah, pra-lanjutan, dan lanjutan, serta kompetensi dan pematangan menulis mahasiswa, dosen dapat memodifikasi rubrik analitik yang cukup merekomendasikan kualitas yang diperlukan dari teks deskriptif atau mencakup lebih luas. komponen kualitas rubrik. Temuan ini menyiratkan bahwa rubrik penilaian analitik memasukkan metode penilaian yang berpengaruh ke dalam aktivitas sehari-hari.
\end{abstract}

Kata Kunci: penskoran analitik, teks deskriptif, pendidikan bahasa Sunda, validitas dan reliabilitas

\section{INTRODUCTION}

In this millennial era, writing is still considered to be a difficult skill. The difficulty lies in the fact that writing forces the mind to convert thoughts and emotions into a cognitive path in written output. In addition, others define writing as an extremely laborious task because many sub-components are required to be combined into a single discourse. Such an issue is also faced by Indonesian higher education students, particularly sophomore students of the department of Sundanese language education.

Writing difficulties potentially result in detrimental psychological effects such as confusion, boredom, and even frustration. Balta (2018) and 
Ekmekçi (2018) have shown that writing anxiety should be decreased to positively affect students' writing skills. Anxiety in writing is a reflection of students' strategy to approach or avoid writing activity. Students are generally not confident in manipulating all aspects of writing (syntactic and morphological structures) in order to express their ideas (Schirmer \& Bailey, 2000). In this kind of situation, these students have to deal with the fact that writing skills are still used to measure students' achievements upon their grading levels, mappings, and punishments that categorize students into fast and/or slow learners (Meisels et al., 2008).

In the process of making an excellent writing product, feedback gained from both teachers and peers is essential. As mentioned by (Sumekto, 2018), such feedback from two parties represents honesty, a sense of care, communication, and collaboration. In practical situations, writing is an object of study and principles of communicative language teaching. Therefore, there would appear, eventually, two-sided functions of writing, namely a system of communication and an instrument for learning (Weigle, 2002). To provide valuable insights into a learning process, lecturers need to deal with feedback commentaries in the form of social interaction, self-reflection, and aspects of content (organization, grammar, vocabulary, and mechanics) that allow students to make revisions ( $\mathrm{Wu} \&$ Schunn, 2021; Yu, 2021).

The magnitude of writing feedback is a crucial factor allowing students to collect and document their own progress by consulting specific analytical rubrics provided by their lecturers. Even though it is a time-consuming process since the lecturer is required to assess a text several times, the use of an analytical rubric has contributed to score a text in its substantial aspects. On this issue, $\mathrm{Yu}$ et al. (2020) have generated various feedback strategies (scoring feedback, process-oriented feedback, expressive feedback, peer and self-feedback, and written corrective feedback) to enhance students' motivation and engagement. With all complex situations in implementing the process, feedback on students' performance is surely needed to point to personal scoring criteria.

The use of an analytical rubric also promotes higher-order thinking processes. Nurgiantoro (2018) believes that a writing process can design a critical thinking process in using language. To underpin the ideal process, the rubric is needed to indicate students' writing products, evaluate the texts, and determine the quality of the texts. It appears that the intended rubric is universal and not designed for only a single genre but can be applied to other genres. A specific score can assign each feature in the texts. However, the focus should be on conventional features such as grammar, mechanism, and style (Chen et al., 2017) and features such as thesis, organization, and idea development.

It is important to consider some fundamental aspects in writing products to portray positive and negative matters in students' texts. The respective aspects are then combined with raters' decision-making behaviors (Şahan \& Razı, 2020). The importance of a rubric can be identified in this context. A fixed analytical rubric and score can maintain the consistency of judgment compared with a traditional written examination style. This type of rubric can display significant information of students' performance and accommodate varied levels of students' abilities (Wiseman, 2008).

A reliable rubric should have a specific scale of scores added by description to determine the evaluation of each text parameter. In a general context, the scores range from zero (the lowest) to four (the highest) (Martinez, 1997). For each score, there should be a concise description of all levels of performance. It prevents the evaluation that is limited to grammatical issues but promotes wider discussion on details, content, and fluency. By doing so, students are encouraged to be active in this process by entertaining the feedback. Prior studies (Meletiadou, 2012; Polston, 2014) emphasize that specific rubric provides valuable impacts on students' perceptions of having comments and feedback from lecturers and peers.

Peer feedback is the representation of a student-centered approach. Students are motivated to produce a better text through several revisions based on students' comments. Students, as a consequence, are engaged in varied activities. This practice, therefore, allows students to strengthen their cognitive awareness. It is also interesting to compare the different versions of rubrics. (Spence, 2010) proposes a 6-point rating scale that defines 1 to 3 as low scores and 4 to 6 as high scores. This rubric is more complex as the wording is a continued idea from beginning to end in the text. Therefore, positive and negative wordings are important to build interactive and inviting information and a satisfying ending. The components can be related to evidence and 
analytical information, focus, process, coherence, and public awareness.

In relation to the present study, some studies capture the feedback in practical settings. Baksh et al. (2016) believed that methods of learning and perception on assessment are influenced by students' language use and academic level. This, in other words, refuses the generic function of rubric in enhancing the quality of students' writing products. Students' cognitive and social situations inevitably become a significant factor in making a successful process of writing. This understanding may have been acknowledged through accommodating students' needs in-class activities.

Guasch et al. (2019) strongly criticise that most research on feedback only puts the attention to how to make valuable feedback rather than understanding how students take the feedback as a core point to develop their texts. Therefore, this study attempts to reveal evidence of how students deal with and use feedback in writing. In a practical situation, the use of feedback allows students to engage in more cognitive and metacognitive activities. The combination of types of feedback can objectively make students obtain better final scores. Moreover, Lim \& Renandya (2020) reveal that corrective feedback has the potential to enhance grammatical accuracy. It also highlights the moderate effectiveness of all types of feedback. In the context of L2, this is, based on the finding, related to learners' proficiency. Giving feedback should be continued by collaborating learners' readiness to develop all aspects of language proficiency.

Henry et al. (2020) are in a position to acknowledge the importance of giving feedback to students and also to acknowledge the problems in determining the number of sessions as a requirement to produce a good text. This study suggests that there should be a conditional case for each level of students' competence. It takes longer time to notice and provide significant feedback. However, a better time-saving option may also exist when peer feedback can be employed in an effective method. Regarding the analytical score, Mubarok (2017) has indicated findings about the contribution of writing feedback in the Indonesian context. By considering the analytical scores, mistakes and weaknesses of the text are explored and corrected. This then contributes to the increased scores obtained by students for their texts.

Nonetheless, there is still a gap between using a rubric and analytical scores to enhance students' performance in writing, specifically for students from the Department of Sundanese language education. Therefore, this present study is intended to uncover the factual evidence of whether the use of a rubric can enhance valid judgment. This process employed the validity and reliability scoring system. After that, it is also imperative to examine the functions of rubrics to promote sophomores' learning and develop instructions from lecturers in the department of Sundanese language education. This study objectively examines students' descriptive writing in the Sundanese language by considering the analytical scoring assessment functions.

\section{METHODS}

The present study took place at undergraduate sophomores of the department of Sundanese language education in a public university. 45 sophomore students were selected to be the respondents. This study was implemented in the odd running semester of 20 weeks. At the initial stage, the observation of the lecturer's writing class was conducted in two sessions a week. In the odd semester, one single lesson plan on writing descriptive texts was implemented in four meetings for classes A and B.

In this session, the students were required to produce two descriptive texts. They were required to have their first, second, and final drafts for each text. The lecturer had revised all drafts. The revised process included giving written feedback on each draft and displaying it during the class. Eventually, the students were required to submit their final drafts in the final week of the semester. After having the lecturer's permission, the final drafts were used as data in this study.

The assessment on the first draft was about components of grammar and punctuation. This assessment inherently suggests that the focus of a checklist is only on grammatical accuracy and word choices. Based on the identification, to highlight errors, the lecturer underlined errors and gave symbols to define what such errors meant. Later, the lecturer checked the symbols to link the current errors to the second draft. In the final draft, there were written feedback, commentaries, statements, and questions that covered all mechanics of writing and aspects of linguistics. The respective identifycation was adopted from a general analytical rubric in the higher education level as proposed by Kaven (2013).

The present study conducted the assessment by considering the first draft as an assignment in class and potentially as homework for 
students. Each draft was filled with the written feedback. The students had to make revisions based on the feedback after the class. In the final draft, the lecturer displayed feedback in oral and written presentations in the class. Eventually, the final texts were examined to give proper scores based on the analytic scoring rubric.

The data of this study were obtained from sophomores' descriptive text performance. 45 students of classes A and B were required to take a guided descriptive text as directed by the lecturer. To obtain the Cronbach's alpha coefficient, 27 sophomores from classes C and D were also directed to write a descriptive text. The descriptive writings of sophomores were statistically evaluated using a descriptive and factor analysis. All descriptive texts were read twice and categorized, and remarks on organizing topics were immediately supplied on the transcriptions. The grading was based on the overall number of mistakes and the amount of inappropriateness made. The sophomores made revisions based on written input from the lecturer.

\section{FINDINGS AND DISCUSSION Findings}

At the first stage, the grammar component in the data analysis describes the descriptive and frequency statistics results in Table 1. The results showed that 6 or $13.33 \%$ of sophomores had a poor level of grammatical competence, 36 or $80 \%$ performed a fair level of grammar competence, and another 3 or $6.67 \%$ displayed a high ranking of grammar competence. Based on the analysis, no students obtained both failed and outstanding grades in their descriptive texts on grammatical competence.

The analysis also showed that, by using an analytical scoring evaluation, the lowest score of the component was 2.00 , and the maximum score was 4.00. Furthermore, the mean $(n=45)$ was 3.00 , with a standard deviation of .477 . By having $77.8 \%$, the overall accomplishment of the grammar competence was at a fair level.

The analysis of the punctuation aspect had been conducted. The description of statistical results can be seen in Table 2. The analysis showed that 8 or $17.78 \%$ of students performed a fair level of punctuation understanding, 35 or $77.78 \%$ had a good level of punctuation understanding, and 2 or $4.44 \%$ demonstrated a high ranking level of punctuation skill. Based on the analysis, no students obtained either failed or poor grades in their descriptive text on punctuation competence. The analysis also indicated that, by using an analytical scoring evaluation, the lowest score of the component was 3.00, and the maximum score was 5.00. Furthermore, the mean $(\mathrm{n}=45)$ was 3.93 , with a standard deviation of .495 . By having $75.6 \%$, the overall accomplishment of the grammatical competence was on a good level.

The analysis of the coherence aspect was conducted and showed varied results. The description of statistical results can be seen in Table 3. The analysis showed that 19 or $42.2 \%$ students performed a fair level of coherence understanding, 25 or $55.6 \%$ had a good level of coherence understanding, and 1 or $2.2 \%$ demonstrated a high-ranking level of coherence skill. Based on the analysis, no students obtained either failed or pool grades in their descriptive text on coherence competence. The analysis also revealed that, by using an analytical scoring evaluation, the lowest score of the component was 3.00, and the maximum score was 5.00. Furthermore, the mean $(n=$ 45) was 3.60, with a standard deviation of .495. By having $55.6 \%$, the overall accomplishment of the coherence competence was on a good level.

In terms of the analysis of the cohesion aspect, a description of statistical results can be seen in Table 4. The results showed that 2 or $4.4 \%$ of students had a poor level of cohesion competence, 31 or $68.9 \%$ students performed a fair cohesion understanding, and 12 or $26.7 \%$ had a good cohesion understanding. Based on the analysis, no students obtained either failed or excellent grades in their descriptive text on cohesion competence. The analysis also indicated that, by using an analytical scoring evaluation, the lowest score of the component was 2.00, and the maximum score was 4.00 . Furthermore, the mean $(\mathrm{n}=45)$ was 3.22 , with a standard deviation of .517 . By having $68.9 \%$, the overall accomplishment of the coherence competence was at the fair level.

As for the analysis of the content aspect, a description of statistical results can be seen in Table 5. The results showed that 5 or $11.1 \%$ of students had a poor level of content competence, 19 or $42.2 \%$ students performed a fair level of content understanding, and 14 or $31.1 \%$ had a good level of cohesion understanding, and 7 or $15.6 \%$ demonstrated a high ranking level of content skill. Based on the analysis, no students can be categorized as having poor content understanding. The analysis also showed that, by using an analytical scoring evaluation, the lowest score of the component was 2.00 , and the maximum score was 5.00. Furthermore, the mean $(n=45)$ 
was 3.51 , with a standard deviation of .895 . By having $42.2 \%$, the overall accomplishment of the coherence competence was on a fair level.

It should be then noted that the descriptive text also reflects all earlier mentioned aspects. It is called as descriptive parameters. The results of analyzing descriptive are displayed in Table 6.
The results of each component are as follows: grammatical aspects $(M=3.00 ; S D=.476)$, punctuation competence $(M=3.93 ; S D=.495)$, coherence competence $(M=3.60 ; S D=.539)$, cohesion competence $(M=3.22 ; S D=.517)$, and content competence $(M=3.51 ; S D=.894)$.

Table 1. The Achievement of Grammar Competence Performed by Students

\begin{tabular}{clcccc} 
& & Frequency & Percent & Valid Percent & Cumulative Percent \\
\cline { 2 - 6 } Valid & 2.00 & 6 & 13.33 & 13.33 & 20.0 \\
& 3.00 & 36 & 80.00 & 80.00 & 80.0 \\
& 4.00 & 3 & 6.67 & 6.67 & 100.0 \\
& Total & 45 & 100.0 & 100.0 & \\
\hline
\end{tabular}

Table 2. The Achievement of Punctuation Competence Performed by Students

\begin{tabular}{cccccc} 
& & Frequency & Percent & Valid Percent & Cumulative Percent \\
\cline { 2 - 6 } Valid & 3.00 & 8 & 17.78 & 17.78 & 22.22 \\
& 4.00 & 35 & 77.78 & 77.78 & 77.78 \\
& 5.00 & 2 & 4.44 & 4.44 & 100.0 \\
& Total & 45 & 100.0 & 100.0 & \\
\hline
\end{tabular}

Table 3. The Achievement of Coherence Competence Performed by Students

\begin{tabular}{clcccc}
\hline \multirow{4}{*}{ Valid } & Frequency & Percent & Valid Percent & Cumulative Percent \\
\cline { 2 - 6 } & 3.00 & 19 & 42.2 & 42.2 & 42.2 \\
& 4.00 & 25 & 55.6 & 55.6 & 97.8 \\
& 5.00 & 1 & 2.2 & 2.2 & 100.0 \\
\hline
\end{tabular}

Table 4. The Achievement of Cohesion Competence Performed by Students

\begin{tabular}{clcccc}
\hline \multirow{4}{*}{ Valid } & Frequency & Percent & Valid Percent & Cumulative Percent \\
\cline { 2 - 6 } & 2.00 & 2 & 4.4 & 4.4 & 4.4 \\
& 3.00 & 31 & 68.9 & 68.9 & 73.3 \\
& 4.00 & 12 & 26.7 & 26.7 & 100.0 \\
& Total & 45 & 100.0 & 100.0 & \\
\hline
\end{tabular}

Table 5. The Achievement of Content Competence Performed by Students

\begin{tabular}{cccccc} 
& & Frequency & Percent & Valid Percent & Cumulative Percent \\
\cline { 2 - 6 } Valid & 2.00 & 5 & 11.1 & 11.1 & 11.1 \\
& 3.00 & 19 & 42.2 & 42.2 & 53.3 \\
& 4.00 & 14 & 31.1 & 31.1 & 84.4 \\
& 5.00 & 7 & 15.6 & 15.6 & 100.00 \\
& Total & 457 & 100.0 & 100.0 & \\
\hline
\end{tabular}

Table 6. The Performance of Students' Descriptive Text

\begin{tabular}{lccccccccc}
\hline Descriptive & $\mathrm{N}$ & Min. & Max. & Mean & \multicolumn{2}{c}{ Dev. } & \multicolumn{2}{c}{ Skewness } & \multicolumn{2}{c}{ Kurtosis } \\
\cline { 2 - 10 } Texts & Stat & Stat & Stat & Stat & Stat & Stat & Std. Err & Stat & Std. Err \\
Grammar & 45 & 2.00 & 4.00 & 3.0000 & .47673 & .000 & .354 & 1.827 & .695 \\
Punctuation & 45 & 3.00 & 5.00 & 3.0333 & .49543 & -.162 & .354 & 1.320 & .695 \\
Coherence & 45 & 3.00 & 5.00 & 3.6000 & .53936 & .036 & .354 & -1.079 & .695 \\
Cohesion & 45 & 3.00 & 4.00 & 3.2222 & .51737 & .284 & .354 & .031 & .695 \\
Content & 45 & 3.00 & 5.00 & 3.5111 & .89499 & .164 & .354 & -.676 & .695 \\
Valid N & 45 & & & & & & & & \\
\hline
\end{tabular}

Table 7. The Result of Chi-Square Test

\begin{tabular}{lccccc}
\hline & Grammar & Punctuation & Coherence & Cohesion & Content \\
\hline Chi-Square & $40.000^{\mathrm{a}}$ & $36.400^{\mathrm{b}}$ & $20.800^{\mathrm{a}}$ & $28.933^{\mathrm{a}}$ & $11.089^{\mathrm{b}}$ \\
Df & 2 & 2 & 2 & 2 & 3 \\
Asy. Sig & .000 & .000 & .000 & .000 & .011 \\
\hline
\end{tabular}


In the present study, a 5-point-Likert-scale questionnaire was used as a tool to deal with the analytic scoring assessment. It was intended to construct the students' performance in writing descriptive text. For 45 sophomore students of the Sundanese language education department, the statistics results are as follows: grammatical competence's skewness (.000) and kurtosis (1.827), punctuation competence's skewness ($.162)$ and kurtosis (1.320), coherence competence's skewness (.036) and kurtosis (-1.079), cohesion competence's skewness (.284) and kurtosis (tailedness of a distribution) (.031), and content competence's skewness (.164) and kurtosis (-.676). The results of skewness and kurtosis have confirmed that the distribution of data was normal. The analysis also showed that, in the descriptive texts, grammatical competence had the lowest mean and punctuation competence had the highest mean.

The analysis was continued by using a chi-square test as shown by Table 7 . The components of descriptive texts were analyzed in different characteristics. The statistical calculation showed that the overall difference among the components of descriptive texts was significant. The results were $\mathrm{c}^{2}=40.000(2, n=45)$, $p<.000$ for the competence of grammar, $\mathrm{c}^{2}=$ $36.400(2, n=45), p<.000$ for the competence of punctuation, $\mathrm{c}^{2}=20.800(2, n=45), p<.000$ for the competence of coherence, $\mathrm{c}^{2}=28.933(2, n=$ 45), $p<.000$ for the competence of cohesion, and $\mathrm{c}^{2}=11.089(3, n=45), p<.011$ for the competence of content. In this situation, there was no significant difference in the majority (sample size $n=45$ ) of students' descriptive text in the Sundanese language. The description parameters are (1) 0 cells (.0\%) have expected frequencies less than 5 . The minimum expected cell frequency is 15.0 , and (2) 0 cells $(.0 \%)$ have expected frequencies less than 5 . The minimum expected cell frequency is 11.3.

\section{Discussion}

This study seeks to determine whether the descriptive text analytical scoring system can be used as an effective instructional approach for sophomores in the Sundanese education department. Full comprehension of this text is experimentally based on sophomores' analytical score components, such as grammar, punctuation, coherence, cohesiveness, and substance, as parts of the required features of the descriptive text. As conveyed in sophomores' descriptive texts, a wellformatted written output typically begins with the title shown at the beginning of the writing section. The title should be centered, and the first letter should be typed or printed in capital letters if the conditions are followed. The first sentence should be meant when beginning a new paragraph. A writer generally writes three to five phrases before going on to the second paragraph, which is usually double-spaced. According to the facts, sophomores' descriptive texts still have some issues to work on. They fail to provide a short and succinct title, and they continue to write the paragraphs without regard for the required format. These facts may define certain students' academic backgrounds, in which they did not previously have adequate familiarity with writing components. However, some of them have been created with the right specifications.

The following component focuses on grammar, demonstrating knowledge of the connection between punctuation and sentence structure (Martinez, 1997). It must be an efficient complex structure with few mistakes in agreement, tense, number, word order or function, articles, pronouns, and prepositions (Kargozari et al., 2012; Pappamihiel et al., 2008). According to the grammatical competency assessed from the average score of sophomores, the result ranks on the lower level. The average score is 3.00, which is considered fair.

As emphasized by Kargozari et al. (2012); and Pappamihiel et al. (2008) and, errors might vary in the usage of the most intricate features. Meanwhile, the sentence structure errors discovered in sophomore descriptive texts correspond to the simple, compound, and complicated sentences. Some errors also contribute to sentence pattern organization, subject and predicate agreement, and either single or paired conjunctions, resulting in some sentence difficulties and complexity to grasp.

The second component of the descriptive text concerns sophomores' punctuation abilities. According to Kargozari et al. (2012) and Pappamihiel et al. (2008), knowledge of norms eliminates few spelling errors expressed in phrases and/or paragraphs. Sophomores may begin and comprehend paragraphing, as well as write with proper capitalization. With a mean of 3.93, the sophomores' punctuation competence ranked first. In the instance of sophomores' punctuation skills, several misspelt words were generated in their paragraphs. When given the option to complete their text, only a few sophomores employed technological devices to assist 
them fix punctuation mistakes, such as spelling, spacing, and capitalization.

The third element weakens coherence and cohesiveness. When the researchers perform classroom observations, these two components are used independently for feedback reasons. The researchers believe that the components should be used together, referring to Meletiadou's (2012) recommendation, in which either coherence or cohesion unifies the paragraphs, and the sophomores gain the coherence component by using simple linking devices to connect one sentence into another in a paragraph. According to Martinez (1997), both coherence and cohesion must provide information in a well-organized thinking, offer fluent and complete presentation, ideas clearly, and apply logical sequencing. Meanwhile, Pappamihiel et al. (2008) emphasize the meaning sequence such that words stick together and support the overall meaning of the descriptive text. According to the coherence and cohesion skill, the outcome ranks second in coherence with a mean score of 3.60, and fourth in cohesion with a mean score of 3.22 .

Some common errors were actually found in the sophomores' introductory statements, in which the paragraphs do not sharpen the thesis statement of their descriptive texts, besides being mandatory to comprehend a clear topic sentence and unnecessary dealing with more than one idea that does not correspond with the topic sentence. Furthermore, the words coherence and cohesion were employed incorrectly in sentences to reflect supporting concepts that address facts and details. The supporting concepts were not in sync with the governing ideas. In reality, certain concepts should not jump from one phrase to the next; sophomores should also highlight the purpose of transitional signals, which are simply meant to connect sentences. As a result, the majority of their descriptive texts are not effortlessly integrated and coherent.

The fourth component is related to the substance of sophomores' descriptive texts. Martinez (1997) adds relevant information to support concepts or conclusions in a text that provides the major ideas clearly and is wellsupported to the topic, resulting in easy-to-read writing (Meletiadou, 2012). Kargozari et al. (2012) and Pappamihiel et al. (2008) state that the content must be knowledgeable, substantive, well-developed materials or thesis, and related to a given topic. In terms of sophomore content competence, the accomplishment ranks third, with a mean score of 3.51 . For better results, sophomores should be aware of their sentences before moving on to the following sentence by doing thorough checks and modifications on any potential errors or mismatches found in their descriptive texts.

Another topic of debate is the suitably analytic scoring rubric, which must be wellprepared in order to accommodate all sophomores in applying it without allowing any room for inadequacy. Before utilizing the rubric, the lecturer must convey important information about how to work with the rubric elements. The right rubric usage is commonly used to identify the effective format and goal of its practice. Cyr et al. (2014) confirmed that a rubric outlines a set of criteria and the standards link to specific learning objectives and may assign a numeric value to correspond with each criteria category, such as grammar, punctuation, coherence, cohesion, and content (Kaven, 2013), and separated and weighted the textual components with a 5point-Likert scale.

According to Spence (2010), each component has its own score scale with descriptive statements and occasionally extends too many descriptions, allowing the present level of accomplishment, strengths, and weaknesses to be diagnosed (Dlugokienski \& Sampson, 2008). Thus, when subjective assignments and written comments on sophomores' descriptive texts are feasible, the implementation of the analytical scoring rubric provides for a standardized performance evaluation to improve consistency (Polston, 2014).

However, In turns out that in this study, the analytical scoring approach took longer to score texts using an analytic rubric because the lecturer had to make several judgments for each writing sample and read the sample multiple times. In addition, the implementation of an analytic grading criterion may divert attention away from the overall impact of the text. Because several score scales are typically summed, some of the information gathered from those scales may be nonsensical. Another drawback found is the information distortion that occurs when the lecturer rated the numerous scales and calculated a single composite score. The professor in charge also took more time to rate holistically rather than analytically, so that the scoring process still had some issues with validity and reliability.

Students' descriptive texts, more than their formal strategies textual communication, uncovers many informative facts. It can be deduced 
from the textual production that Sundanese students' definitions of descriptive facts demonstrate their potential to construct abstract information into reasonable ideas based on their understanding. Since there was no formal written record of particular information, it was often passed down by oral tradition.

The intersection of cultural values and realistic application is extremely important to students of the department of Sundanese language education. Naresh \& Chahine (2013) have shown the significance of social principles and general information in conventional practices. The current research has added more insights to the previous studies by providing new data and evidence. From a modern standpoint, the practice of conducting concepts can face a challenge. Cultural awareness can be a hot topic at times. According to modern viewpoints, logical ideas should be the foundation of certain operations. When modern perspectives agree that human beings can change their minds depending on certain circumstances, it is difficult to rely on a static estimate. This current research confirms the problems expected by Orey \& Rosa (2006).

The present study shows that optimal education entails not only the acquisition of content knowledge and a G.P.A. in the context that competency-based curricula and collaborative learning models suggest, but also the creation of an increasing set of professional competencies that prepare students to solve ambiguous realworld problems.

Weekly exposure to the writing operations of textual presentations and peer-review formative tests was most likely the cause of the students' improved descriptive writing skills. Previous research on the impact of rubric of writing on textual communication competency improvements has yielded mixed results. Students self-reported no change in their perceived textual communication competency when assessing the impact of the analytical rubric on their competency as they relied on group members with previous textual communication experience during group and peer discussion (Spronken-Smith, 2005).

Despite the fact that the students mentioned here improved their skills in writing descriptive texts significantly over the odd semester, their mean scores indicated that their ability was still improving and that they were most likely at the beginning of the ability spectrum. This finding is in line with the self-report findings that textual communication was developed less than problem-solving, time management, and teamwork (Williams \& Handa, 2016).

Understanding the motivational orientation that contributes to the growth of mutual learning competency will help to scale up these gains. The path and orientation of student goal profiles are diverse. Performance goals were not distinguished as well as learning and well-being goals in the research by Wosnitza \& Volet (2012). This finding supports the idea that a positive classroom climate promotes healthy learning and competency growth.

The authors suggested that small groups of collaborative learners be formed with the students' target orientations in mind to optimize the motivational benefits previously discussed for collaborative learning (Blumenfeld et al., 2005). The difficulty that PBL students will encounter in their group work, which includes differences in target orientations, cultural contexts, and material mastery, necessitates explaining the individual and social aspects of motivation for collective learning.

The greater the peer-to-peer motivation for writing (Wosnitza \& Volet, 2012), the greater the competency gains over the semester, and the more groups can be formed a priori, with heterogeneous pairings of students with respect to these considerations. By including the following series of learning phases: socialization, externalization, combination, and internalization, Nonaka's model of knowledge acquisition adds depth to the interpretation of goal orientation (Nonaka et al., 2001). In essence, students have the option of spending more time in group discussions and brainstorming sessions. The result shows identical discussion to Ghufron and Suminta (2020), which focused on using epistemic beliefs to improve students' interaction with the surrounding context to perform optimal academic results.

The main point of this approach, once again, is communicative practices in a realistic context. It encourages and respects students' desire to participate in group discussions in a supportive environment (Rahimipoor, 2016). In this case, students are encouraged to enhance their skills by discussing and putting forward personal effort to improve the quality of the mini-research products when they are given situations based on feedback. The discussion activity can be done in a collaborative setting. 
Despite the fact that students improved their skills in writing descriptive texts significantly, the urge to involve students in the situation of competence growth through a collaborative learning program is critical to prevent a reversal of ability before graduation. As a result, it is the educator's responsibility to create learning environments that gradually integrate previous learning and competency growth through curricula that prioritize peer reviews in the setting of formative assessments rather than summative assessments (Frank et al., 2010). This is especially important as the concept of competency moves away from a mastery of material knowledge and toward the ability to working remotely on ambiguous real-world issues (Epstein \& Hundert, 2002). Consequently, while lecturers have committed to using a novel analytical rubric for writing descriptive texts, there still remain issues to be solved to improve, i.e., its quality in terms of its validity and reliability. More importantly, it is significant for lecturers to motivate students to get more and more actively engaged in learning how to produce texts so that students do not merely aim to achieve high scores in their examinations as a result of the use of such a rubric, but they should be really aware of why they need to have a good mastery of how to write texts of various types.

\section{CONCLUSION}

The implementation of an analytical scoring rubric turned out to have improved the results' reliability and validity. Before evaluating this study, Cronbach's alpha coefficient experimentally revealed the results in terms of important components that affected descriptive writing assessment, namely grammar, punctuation, coherence, cohesiveness, and content. To confirm Cronbach's alpha and indicate the average correlation among the five descriptive writing components that deal with the scale, a 5-point-Likert scale was utilized. The implementation of the analytic scoring evaluation system, on the other hand, encouraged writing class instruction as part of the teaching approach, benefiting both the sophomores and the lecturer.

The outcomes motivated the lecturer to constantly simplify the criteria in order to fit sophomores' descriptive texts, discover significant features, and incorporate the qualities into their own text insights. Furthermore, depending on the text complexity, such as intermediate, pre-advanced, and advanced writing, as well as students' writing competence and maturation, the lecturer may modify the analytical rubric that moderately recommends the necessary qualities of descriptive texts or encompasses a wider component of rubrics qualities. This finding implies that the analytical scoring rubric incorporates the influential scoring method into daily activities.

\section{REFERENCES}

Baksh, A., Mohd Sallehhudin, A. A., Tayeb, Y. A., \& Norhaslinda, H. (2016). Washback effect of school-based english language assessment: A case-study on students' perceptions. Pertanika Journal of Social Sciences \& Humanities, 24(3).

Balta, E. E. (2018). The relationships among writing skills, writing anxiety and metacognitive awareness. Journal of Education and Learning, 7(3), 233-241.

Blumenfeld, P. C., Kempler, T. M., \& Krajcik, J. S. (2005). Motivation and cognitive engagement in learning environments. In R. K. Sawyer (Ed.), The Cambridge Handbook of the Learning Sciences (pp. 475-488). Cambridge University Press. https://doi.org/10.1017/CBO97805118168 33.029

Chen, H.-X., Chen, W., Liu, X., Liu, Y.-R., \& Zhu, S.-L. (2017). A review of the open charm and open bottom systems. Reports on Progress in Physics, 80(7), 76201. https://doi.org/10.1088/1361-6633/aa6420

Cyr, P. R., Smith, K. A., Broyles, I. L., \& Holt, C. T. (2014). Developing, evaluating and validating a scoring rubric for written case reports. International Journal of Medical Education, 5, 18-23. https://doi.org/10.5116/ijme.52c6.d7ef

Dlugokienski, A., \& Sampson, V. (2008). Learning to write and writing to learn in science: Refutational texts and analytical rubrics. Science Scope, 32(3), 14-19. https://doi.org/10.2505/3/sc08_032_03

Ekmekçi, E. (2018). Exploring Turkish EFL students' writing anxiety. The Reading Matrix: An International Online Journal, 18(1), 158-175.

Epstein, R. M., \& Hundert, E. M. (2002). Defining and assessing professional competence. JAMA, 287(2), 226. https://doi.org/10.1001/jama.287.2.226

Frank, J. R., Snell, L. S., Cate, O. Ten, Holmboe, E. S., Carraccio, C., Swing, S. R., Harris, 
P., Glasgow, N. J., Campbell, C., Dath, D., Harden, R. M., Iobst, W., Long, D. M., Mungroo, R., Richardson, D. L., Sherbino, J., Silver, I., Taber, S., Talbot, M., \& Harris, K. A. (2010). Competencybased medical education: theory to practice. Medical Teacher, 32(8), 638645.

https://doi.org/10.3109/0142159X.2010.5 01190

Ghufron, M. N., \& Suminta, R. R. (2020). Epistemic beliefs on field-dependent and field-independent learning style. Jurnal Cakrawala Pendidikan, 39(3), 532-544. https://doi.org/10.21831/cp.v39i3.23800

Guasch, T., Espasa, A., \& Martinez-Melo, M. (2019). The art of questioning in online learning environments: the potentialities of feedback in writing. Assessment \& Evaluation in Higher Education, 44(1), 111-123. https://doi.org/10.1080/02602938.2018.14 79373

Henry, E., Hinshaw, R., Al-Bataineh, A., \& Bataineh, M. (2020). Exploring teacher and student perceptions on the use of digital conferencing tools when providing feedback in writing workshop. Turkish Online Journal of Educational

Technology-TOJET, 19(3), 41-50.

Kargozari, H. R., Ghaemi, H., \& Heravi, M. A. (2012). Cohesive devices in argumentative, descriptive, and expository writing produced by Iranian EFL university students. Modern Journal of Language Teaching Methods, 2(3), 25.

Kaven, J. (2013). The development of a valid and reliable general analytic rubric for a college-level public-speaking course. California State University.

Lim, S. C., \& Renandya, W. A. (2020). Efficacy of written corrective feedback in writing instruction: A meta-analysis. TESL-EJ, 24(3), n3. http://www.teslej.org/wordpress/sub_howto/submit-proc/

Martinez, K. (1997). The effect of a rubric on evaluating and improving student writing. Caldwell College.

Meisels, S. J., Xue, Y., \& Shamblott, M. (2008). Assessing language, literacy, and mathematics skills with work sampling for head start. Early Education \& Development, 19(6), 963-981. https://doi.org/10.1080/104092808019718 90

Meletiadou, E. (2012). The impact of training adolescent EFL learners on their perceptions of peer assessment of writing. Research Papers in Language Teaching \& Learning, 3(1). https://rpltt.eap.gr/images/2012/03-01240-Meletiadou.pdf

Mubarok, H. (2017). Students' perception toward the implementation of peer assessment in writing: Before and after revision. Celt: A Journal of Culture, English Language, Teaching \& Literature, 17(1), 13-26. https://doi.org/10.24167/celt.v17i1.1136

Naresh, N., \& Chahine, I. (2013).

Reconceptualizing research on workplace mathematics: Negotiations grounded in personal practical experiences. REDIMAT, 2(3), 316-342. https://doi.org/10.4471/redimat.2013.34

Nonaka, I., Konno, N., \& Toyama, R. (2001). Knowledge emergence: Social, technical, and evolutionary dimensions of knowledge creation. Oxford University Press.

Nurgiantoro, B. (2018). Penilaian otentik dalam pembelajaran bahasa. UGM PRESS.

Orey, D. C., \& Rosa, M. (2006). Ethnomathematics: Cultural assertions and challenges towards pedagogical action. The Journal of Mathematics and Culture, 1(1), 57-78.

Pappamihiel, N. E., Nishimata, T., \& Mihai, F. (2008). Timed writing and adult Englishlanguage learners: an investigation of first language use in invention strategies. Journal of Adolescent \& Adult Literacy, 51(5), 386-394. https://doi.org/10.1598/JAAL.51.5.2

Polston, K. (2014). Self-and peer-assessment of product creativity with a rubric in a collaborative environment: A research study with undergraduate textile and apparel designers. North Carolina State University.

Rahimipoor, S. (2016). Evaluating the effects of drama techniques on improving the writing competency of the EFL learners. Nova Journal of Humanities and Social Sciences, 1(1).

Şahan, Ö., \& Razı, S. (2020). Do experience and 
text quality matter for raters' decisionmaking behaviors? Language Testing, 37(3), 311-332. https://doi.org/10.1177/026553221990022 8

Schirmer, B. R., \& Bailey, J. (2000). Writing assessment rubric. TEACHING Exceptional Children, 33(1), 52-58. https://doi.org/10.1177/004005990003300 110

Spence, L. K. (2010). Discerning writing assessment: Insights into an analytical rubric. Language Arts, 87(5), 337. https://library.ncte.org/journals/la/issues/v 87-5/10535

Spronken-Smith, R. (2005). Implementing a problem-based learning approach for teaching research methods in geography. Journal of Geography in Higher Education, 29(2), 203-221. https://doi.org/10.1080/030982605001304 03

Sumekto, D. R. (2018). Investigating the influence of think-pair-share approach toward students' reading achievement. Lingua Cultura, 12(2), 195. https://doi.org/10.21512/lc.v12i2.4011

Weigle, S. C. (2002). Assessing writing. Cambridge University Press. https://doi.org/10.1017/CBO97805117329 97

Williams, D. P., \& Handa, S. (2016). Chemistry student perceptions of transferable \& workplace skills development. New Directions in the Teaching of Physical
Sciences, 11 .

https://doi.org/10.29311/ndtps.v0i11.584

Wiseman, C. S. (2008). Investigating selected facets in measuring second language writing ability using holistic and analytic scoring methods. Teachers College, Columbia University.

Wosnitza, M., \& Volet, S. (2012). Group heterogeneity and homogeneity in personal content goals for a group learning activity: impact on individual appraisals. Applied Psychology, 61(4), 585-604. https://doi.org/10.1111/j.14640597.2012.00507.x

Wu, Y., \& Schunn, C. D. (2021). The effects of providing and receiving peer feedback on writing performance and learning of secondary school students. American Educational Research Journal, 58(3), 492-526. https://doi.org/10.3102/000283122094526 6

Yu, S. (2021). Feedback-giving practice for L2 writing teachers: Friend or foe? Journal of Second Language Writing, 52, 100798. https://doi.org/10.1016/j.jslw.2021.10079 8

Yu, S., Jiang, L., \& Zhou, N. (2020). Investigating what feedback practices contribute to students' writing motivation and engagement in Chinese EFL context: A large scale study. Assessing Writing, 44, 100451. https://doi.org/10.1016/j.asw.2020.100451 